
\title{
$\begin{array}{ll}\text { Research Square } & \begin{array}{l}\text { Preprints are preliminary reports that have not undergone peer review. } \\ \text { They should not be considered conclusive, used to inform clinical practice, } \\ \text { or referenced by the media as validated information. }\end{array}\end{array}$
}

\section{Modification of heavy metals toxicity by Cyanobacteria Nostoc sp. N27P72 and Nostoc sp. FB71 in Culture Conditions}

\author{
Elham Ghorbani \\ Islamic Azad University \\ Bahareh Nowruzi ( $\square$ bahare77biol@gmail.com ) \\ Islamic Azad University https://orcid.org/0000-0001-6656-777X \\ Mssomeh NejadAli \\ Islamic Azad University \\ Azadeh Hekmat \\ Islamic Azad University
}

\section{Research Article}

Keywords: metal removal capability, extracellular polysaccharides, Gas Chromatography Mass Spectrometry, FT-IR, Nostoc, cyanobacteria

Posted Date: April 20th, 2021

DOI: https://doi.org/10.21203/rs.3.rs-414617/v1

License: @ (i) This work is licensed under a Creative Commons Attribution 4.0 International License. Read Full License 


\section{Abstract}

Purpose: Cyanobacteria are ecologically relevant prokaryotes that can be found in environments contaminated with heavy metals. As their photosynthetic machinery imposes high demands for metals, homeostasis of these micronutrients has been extensively considered in cyanobacteria. So far, most studies have focused on treatment of wastewaters using microalgae leads to remarkable reduction of an array of organic and inorganic nutrients, but what takes place in the extracellular environment when cells are exposed to external supplementation with heavy metals remains largely unknown.

Methods: Here, extracellularpolymeric substances (EPS) production in strains Nostoc sp. N27P72 and Nostoc sp. FB71 isolated from different habitats are reported and compared. Cultures of both strains, supplemented with either glucose, sucrose, lactose or maltose showed that production of EPS and cell dry weight was boosted by maltose supplementation.

Result: Nostoc sp. N27P72 which was isolated from lime stones was higher, resulting in $9.1 \pm 0.05 \mu \mathrm{g} / \mathrm{ml}$ and $1.01 \pm 0.06 \mathrm{~g} / \mathrm{l}$ in EPS and cell dry. The cell cultures tested for their ability to remove $\mathrm{Cu}(\mathrm{II}), \mathrm{Cr}(\mathrm{III})$ and $\mathrm{Ni}(\mathrm{II})$ in media culture containing the maltose and without maltose as control culture. Remarkably, we showed that although these elements can be toxic, supplementing the media culture can effectively sequester their toxic effects by increasing the production of EPSs, carbohydrates and total soluble proteins in comparison to control. The crude EPS showed metal adsorption capacity assuming the order $\mathrm{Ni}(\mathrm{II})>\mathrm{Cu}(\mathrm{II})>\mathrm{Cr}(\mathrm{III})$ from metalbinding experiments. Nickel was preferentially biosorbed with a maximal uptake of $188.8 \pm 0.14 \mathrm{mg}$ ( $\mathrm{g}$ cell dry $\mathrm{wt})^{-1}$ crude EPS. FT-IR spectroscopy revealed treatment with Ni made changes in the functional groups and glycoside linkages in both strains. Results of Gas Chromatography Mass Spectrometry (GC-MS) to determine the biochemical composition of Nostoc sp. N27P72 showed that strong Ni(II) removal capability is suspected to be associated with the high Cyclotrisiloxane and 1,2-Benzenedicarboxylic acid content.

Conclusion: The results of these investigates specified that strains Nostoc sp. N27P72 is good candidates for the commercial production of EPS and might be utilized in bioremediation field as an alternative to synthetic and abiotic flocculants.

\section{Introduction}

Nostoc cyanobacteria species are a large and morphologically diverse group of phototrophic prokaryotes which have found in various habitats. They have has drawn more attention because of the presence of outermost polysaccharidic envelopes, often coupled with the capability to release exocellular polysaccharides (RPS) into the culture medium during cell growth (Mota et al., 2015).

Most of these polymers are characterized by an anionic nature, owing to the presence of uronic acids and/or of other charged groups (Pereira et al., 2013). As a result, these polysaccharides typically keep very high affinity to metallic ions and can be considered very promising as chelating agents for the removal of heavy metals from water (Kumar et al., 2007; De Philippis et al. 2001; Cepoi et al., 2019; Kumaran et al., 2011; Ni et al., 2019). 
Many factors influence cell growth and metabolite accumulation in microalgal cell cultures and extracellular polymeric substances (EPSs) including nutrients, such as phosphate and nitrogen, temperature, light intensity, aeration rate, and mixotrophic condosion (Otero and Vincenzini 2003); (Helm et al. 2000). Althought the presence of EPS is extremely preserved among cyanobacteria, not much is recognized about factors that maximize EPS biosynthesis and affecting biosorption capacity (Pereira et al. 2009; Klock et al. 2007; De Philippis et al. 2000; Yoshimura et al. 2011; Gupta et al., 2017). Some trace amounts ( $\mathrm{gL}^{-1}$ ) such as copper, cobalt and nickel are essential by cyanobacteria strains as cofactors for the enzymatic activities. Unlike organic contaminants, heavy metals such as, copper and lead are main pollutants of freshwater due to their inherent nature of being persistent, toxic, recalcitrant and non-biodegradable (Micheletti et al., 2008). On the other hand, heavy metal ion concentrations at ppm $\left(\mathrm{mgL}^{-1}\right)$ level are known to be toxic to the organisms because of irreversible inhibition of many enzymes by the heavy metal ions. Heavy metal uptake capacity of algal biomass has proved to be the highest due to the presence of polymers such as polysaccharides, proteins or lipids on the cell wall surface containing functional groups such as amino, hydroxyl, carboxyl and sulfate, which can act as binding sites for metals (Pereira et al., 2015). A number of articles have been published on phycoremediation investigation and severlal authors have established the fact that treatment of wastewaters using algae, microalgae particularly leads to remarkable reduction of an array of organic and inorganic nutrients, including some of the toxic chemicals (Anjana et al., 2007; Essa and Mostafa., 2012; Farooqui et al., 2017; Principe et al., 2020; Devi and Mehta., 2014). Our previous research found that cell growth and EPS production are highly dependent on the culture conditions. There is no correlation between cell growth and EPS production for cultures being grown in different sources of nitrogen. In contrast, light intensity and cell growth in mixotrophic condition at 150 or $50 \mu \mathrm{mol}$ photon $\mathrm{m}^{-2} \mathrm{~s}^{-1}$ have had a highly positive effect on EPS production. In salty grown cultures, thick layers of ASN_M strain prevent the cells from $\mathrm{NaCl}$ stress and hence its growth is maintained without inhibition under the $\mathrm{NaCl}$ stress (Nowruzi et al., 2013).

This study was undertaken to assess modification of metal removal capability of two Nostoc strains isolated from different habitats, for their ability to remove $\mathrm{Cr}(\mathrm{III}), \mathrm{Cu}(\mathrm{II})$ and $\mathrm{Ni}(\mathrm{II})$ from aqueous solutions. We thought that the strain of Nostoc sp. N27P72 that is isolated from lime stones of Khuzestan province have many features which include high tolerance to different abiotic stress such as drought and high density of light that make it ideal candidate for the selective removal and concentration of heavy metals, compared to aquatic strain.

The main objective of this work is the use of the mixotrophic conditions to optimize the biosorption controllable factors for the maximum metal removal efficiency of algal biomass. Lead, Nickel and copper were selected because of their contrasting toxicity and essentiality. Furthermore, cell dry weight, carbohydrates content, total soluble proteins, analysis of functional groups by fourier transformed infrared (FT-IR) spectroscopy and Chemical composition of the lyophilized EPS by coupled gas chromatography -mass spectrometry (GC-MS) have been investigated. To the best of our knowledge, modification of culture media by Nostoc species has not been reported for the removal of heavy metals and hence this study would be of great importance in increasing the capability of bioremediation of metals from aqueous environment.

\section{Materials And Methods}




\section{Materials}

All materials and reagents were purchased from Sigma-Aldrich unless otherwise specified.

\section{Cyanobacterial strains}

Nostoc sp. N27P72 and Nostoc sp. FB71 obtained from the Cyanobacteria Culture Collection (CCC) and the ALBORZ Herbarium, at the Science and Research Branch, Islamic Azad University, Tehran.

\section{Culture conditions}

Nostoc sp. N27P72 was belong to lime stones of Khuzestan province and Nostoc sp. FB71 was isolated from fresh water of Golestan province. Nostoc sp. N27P72 was grown at modified Z8IX medium and Nostoc sp. FB71 was cultured on liquid media BG11 medium (nitrate free) (Rippka et al. 1979) and pH was adjusted to 7.1. Cultures were incubated in a culture chamber at $28^{\circ} \mathrm{C}$, and were provided with continuous artificial illumination of approximately $15 \mu \mathrm{mol} \mathrm{m}^{-2} \mathrm{~s}^{-1}$ for two weeks (Liu et al., 2014).

the cell cultures used for optimization of metal removal capability were grown in broth $(25 \mathrm{ml}$ in $250 \mathrm{ml}$ baffled shake flasks) containing the sugars glucose, maltose, lactose, and sucrose, respectively, as additional carbon source at the concentrations $10 \mathrm{~g} / \mathrm{l}$ and were grown for $48 \mathrm{~h}$. Samples were taken after $6,12,24$, and $48 \mathrm{~h}$ and were analysed for total produced EPSs, cell dry weight and sugar content. A parallel control experiment was carried out using broth media cultures of Z8IX and BG11 without carbon source supplementation.

\section{Determination of cell biomass}

Cyanobacteria growth was quantitatively determined by measuring cell dry weight. First cells washed and resuspended in $2 \mathrm{ml}$ of 0.05 M EDTA sodium salt solution (Sardari et al., 2013) and the mixture was shaken at $4{ }^{\circ} \mathrm{C}$ for $4 \mathrm{~h}$ to remove any capsular EPS. Then cells were harvested and dried in an oven set at $100{ }^{\circ} \mathrm{C}$. The cell dry weight was measured periodically until a constant weight was reached (Nowruzi et al., 2013).

\section{Isolation of exopolysaccharides}

Strains Nostoc sp. N27P72 and Nostoc sp. FB71 were taken at different times from the cultivations were centrifuged at $4000 \mathrm{rpm}$ for $30 \mathrm{~min}$ at $4{ }^{\circ} \mathrm{C}$ (SigmaPK). The EPSs were precipitated by adding ethanol and storing overnight at $4 \circ \mathrm{C}$. precipitates were harvested and put in a fume hood to evaporate the remaining ethanol. The precipitates then were dissolved in milliQ water and lyophilized (Labconco freeze dry system) to obtain the crude EPSs (Nowruzi et al., 2013).

\section{Selectivity in the heavy metal removal}

The cell cultures were grown in Z8IX and BG11 media culture containing the maltose and without maltose as control culture, were tested for their ability to remove $\mathrm{Cu}(\mathrm{II}), \mathrm{Cr}(\mathrm{III})$ and $\mathrm{Ni}(\mathrm{II})$. The cultures $(400 \mathrm{ml}$ of cell suspensions in $1000 \mathrm{ml}$ Erlenmeyer flasks) were grown for 10-15 days in an orbital Incubator (Gallenkamp, Loughborough,UK) at $30 \pm 1^{\circ} \mathrm{C}$ under continuous illumination provided by cool white fluorescent tubes giving 
a mean photon flux of $100 \mu \mathrm{mol}$ photon $\mathrm{m}^{-2} \mathrm{~s}^{-1}$ photosynthetic active radiation at the flask surface. Before their use for the experiments, aliquots of the cultures were confined in dialysis tubing and pretreated with 0.1 $\mathrm{N} \mathrm{HCl}$ and then dialysed against water. Next, the cultures were suspended into metal solutions with continuous stirring. Working solutions of $10 \mathrm{mg} \mathrm{l}^{-1} \mathrm{Cr}(\mathrm{III}), \mathrm{Cu}(\mathrm{II})$ and $\mathrm{Ni}(\mathrm{II})$ were prepared, for each metal, by dilution of $1000 \mathrm{mg} \mathrm{l}^{-1}$ standard solutions ( $\mathrm{pH}$ 5.0); the experiments were performed in a thermostat at a temperature of $25 \pm 1^{0} \mathrm{C}$. For the determination of the kinetics of metal removal, $5 \mathrm{ml}$ samples were withdrawn at known intervals, centrifuged (10 min at $10000 \mathrm{~g}$ ) and filtered through a $0.45 \mathrm{~lm}$ membrane. The metal uptake was calculated from the difference between the concentrations of the metals in solution, determined with an Atomic adsorption spectrometer (SpectrAA 10 plus, Varian, CA, USA), at the beginning and end of exposure with the cyanobacterial cell suspensions; $\mathrm{Cu}(\mathrm{II}), \mathrm{Ni}(\mathrm{II})$ and $\mathrm{Cr}(\mathrm{III})$ concentrations were determined at 232.0, 359.9 and $324.7 \mathrm{~nm}$ respectively.

The amount of metals removed in blanks carried out in parallel without the addition of cyanobacterial cells was subtracted from the experimental values gained in the experiments with the cyanobacterial cultures. All the experiments were performed at least in triplicate and the data are reported as mean values \pm standard deviation. The metal uptake $\mathrm{q}$, expressed as $\mathrm{mg}$ of metal removed per $\mathrm{g}$ of dry biomass, was calculated as: $\mathrm{q}$ $=\left(C_{i}-C_{t}\right) / m$. The concentration of the biomass was determined as dry weight $\left(\mathrm{g} \mathrm{l}^{-1}\right)$ by filtering the cell suspension on $0.45 \mathrm{Im}$ filters and by drying the filters at $100^{\circ} \mathrm{C}$ until constant weight (De Philippis et al., 2003) (Micheletti et al., 2008).

In order to confirm the affection of the metals and to determine the interaction of the cations within the different functional groups of the EPS, metal solution and all incubated EPS were lyophilized after the $24 \mathrm{~h}$ dialysis (lyophilized EPS containing maltose and metal solution of $\mathrm{Cu}(\mathrm{II}), \mathrm{Cr}(\mathrm{III})$ and $\mathrm{Ni}(\mathrm{II})$ ) and total produced EPSs, total soluble proteins, carbohydrate content and chemical composition were measured.

\section{Analyzing of carbohydrates content}

$5 \mathrm{mg}$ of the sample was mixed with $2.5 \mathrm{~cm}^{3}$ of Antrone reagent $(0.65 \%)$ in $\mathrm{H}_{2} \mathrm{SO}_{4}(65 \%)$. The mixture was incubated for $35 \mathrm{~min}$ at $100{ }^{\circ} \mathrm{C}$. The absorbance was measured at $620 \mathrm{~nm}$. Carbohydrates content was computed using a calibration curve (Zinicovscaia et al., 2016).

\section{Estimation of total soluble proteins}

$20 \mathrm{mg}$ of EPS were ressuspended in $1 \mathrm{ml}$ of deionized water and sonicated and successively diluted until a homogenous solution was obtained. Protein content was determined according to the Lowry et al. (1951), and a calibration curve was constructed using serum albumin.

\section{Analysis of functional groups by FT-IR}

$2 \mathrm{mg}$ of lyophilized EPS was grinded with $100 \mathrm{mg}$ dry $\mathrm{KBr}$ and pressed into a mold in a uniaxial hydraulic press. FT-IR spectra of the purified EPSs fractions were recorded in the $4000-400 \mathrm{~cm}^{-1}$ region using a FT-IR system (Nicolet is5, Ther-moFisher Scientific). The determinations were performed in two independent replicates and are reported as the mean with standard deviations (Mota et al., 2016). 


\section{Chemical composition of the lyophilized EPS}

Chemical composition of extracts of Nostoc sp. N27P72 was evaluated using a coupled gas chromatography -mass spectrometry (GC-MS). The separation of compounds and their analysis was performed using agilent 7000 series Quadrupole GC-MS system with electron impact ionization. The total GC run time was 32 min and the carrier gas was helium. The initial oven temperature was held at $90^{\circ} \mathrm{C}$ for 1 mina and then reached $300^{\circ} \mathrm{C}$ in $13 \mathrm{~min}$, after which it was held at this temperature for $20 \mathrm{~min}$. the injector temperature was $300^{\circ} \mathrm{C}$. Interpretation on mass spectrum GC-MS was conducted using the database of National Institute Standard and Technology (NIST) having more than 62,000 patterns and Fiehn Mass Spectra Libraries. The spectrum of the unispecified component was equaled with the spectrum of the identified components stored in the NIST library. The Name, Molecular weight and Structure of the components of the test materials were ascertained (Sampathkumar and Halith., 2020).

\section{Statistical analysis}

Results of each representative experiment were analyzed by ANOVA, using the statistical software package SPSS version 24 and differences between the groups were detected with Tukey's grouping tests. P(s) values smaller than 0.05 are considered significant. Means and the standard deviation were calculated from the data obtained from three replicates (Nowruzi et al., 2013).

\section{Results}

\section{Growth and EPS production by the two Nostoc strains}

The two Nostoc strains exhibited a distinct difference in growth behavior. As initial trials with the both strains showed that use of disaccharides (maltose, lactose, and sucrose) as carbon source supplementation generally resulted in higher EPS production than the use of monosaccharides (Glucose), moreover the amounts of total produced EPSs, cell dry weight and residual sugar content was higher in Nostoc sp. N27P72 in comparison to Nostoc sp. FB71 in all treatments. Consumption of the monosaccharide glucose, and the disaccharides lactose, lactose and maltose was verified (Fig. 1). In all situations, production of EPS was started in the exponential growth phase and was shown to reamin in the stationary phase. The consumption rate of glucose, maltose, lactose, and sucrose was nearly uniform in both strains and after $48 \mathrm{~h}$ all glucose was not consumed and the residual concentration was 6-6.5 $\pm 0.1 \mathrm{~g} / \mathrm{l}$ in all treatments. The change in cell concentration was very obvious in both strains in cultures adding maltose and reaching to $1.01 \pm 0.06 \mathrm{~g} / \mathrm{l}$ in Nostoc sp. N27P72 and $0.75 \pm 0.16 \mathrm{~g} / \mathrm{l}$ in Nostoc sp. FB71 at $48 \mathrm{~h}$. The increase in cell dry weight might be due to consumption of produced EPS, which was reaching a final EPS concentration of $9.1 \pm 0.05 \mu \mathrm{g} / \mathrm{ml}$ in Nostoc sp. N27P72 and $7.04 \pm 0.1 \mu \mathrm{g} / \mathrm{ml}$ in Nostoc sp. FB71 (at $48 \mathrm{~h}$ ). The experiments using cultures without added sugar, showed a slightly lower maximum cell mass $(0.55 \pm 0.03 \mathrm{~g} / \mathrm{l}$ in Nostoc sp. N27P72 and $0.323 \pm$ 0.05 in Nostoc sp. FB71 after $48 \mathrm{~h}$ ) and the final EPS concentration was $3.3 \mu \mathrm{g} / \mathrm{ml}$ in Nostoc sp. N27P72 and $2.5 \mu \mathrm{g} / \mathrm{ml}$ in Nostoc sp. FB71 after $48 \mathrm{~h}$. This indicates that the $10 \mathrm{~g} / \mathrm{L}$ maltose addition had a small boosting effect on both cell mass and EPS production. 
Addition of glucose did not stimulate cell growth and EPS production in Nostoc sp. N27P72, however it was stimulating in EPS production in Nostoc sp. FB71. The consumption rate of glucose during the first $6 \mathrm{~h}$ was $1.5 \mathrm{~g} / \mathrm{l}$ in Nostoc sp. N27P72 and $2 \mathrm{~g} / \mathrm{l}$ in Nostoc sp. FB71 but decreased to $0.5 \mathrm{~g} / \mathrm{l} \mathrm{h}(6-15 \mathrm{~h})$ and reaching a cell mass of $0.59 \pm 0.21 \mathrm{~g} / \mathrm{l}$ in Nostoc sp. N27P72 and $0.25 \mathrm{~g} / \mathrm{l}$ in Nostoc sp. FB71 at $24 \mathrm{~h}$. After $48 \mathrm{~h}$ the cell mass finally reached $0.79 \pm 0.35 \mathrm{~g} / \mathrm{l}$ in Nostoc sp. N27P72 and $0.38 \mathrm{~g} / \mathrm{l}$ in Nostoc sp. FB71, while production of EPS continued $(1.7 \mu \mathrm{g} / \mathrm{ml}$ in Nostoc sp. N27P72 and $3.9 \mu \mathrm{g} / \mathrm{ml}$ during the whole $48 \mathrm{~h}$ of cultivation. The cell mass obtained in maltose supplemented cultivations resembled that of the lactose supplementation (0.4 $\pm 0.28 \mathrm{~g} / \mathrm{l}$ in Nostoc sp. N27P72 and $0.5 \pm 0.1 \mathrm{~g} / \mathrm{l}$ in Nostoc sp. FB71 after $24 \mathrm{~h}$, maintained at $24 \mathrm{~h}$ as $0.94 \pm$ $0.14 \mathrm{~g} / \mathrm{l}$ in Nostoc sp. N27P72 and $0.66 \pm 0.09 \mathrm{~g} / \mathrm{l}$ in Nostoc sp. FB71. The EPS concentration in this case reached $6.41 \pm 0.13 \mu \mathrm{g} / \mathrm{ml}$ in Nostoc sp. N27P72 and $5.10 \pm 0.26 \mu \mathrm{g} / \mathrm{ml}$ in Nostoc sp. FB71 (after $48 \mathrm{~h}$ ). Sucrose supplemented cultivations showed that the maximum cell concentration was $1.15 \pm 0.21 \mathrm{~g} / \mathrm{l}$ and the concentration of produced EPS was $2.01 \pm 0.15 \mu \mathrm{g} / \mathrm{ml}$ in Nostoc sp. N27P72 and $4.32 \pm 0.19 \mu \mathrm{g} / \mathrm{ml}$ in Nostoc sp. FB71 after $48 \mathrm{~h}$. The results displayed that while the effects on cell mass were slightly small, production of EPS amplified upon adding of the disaccharides maltose and lactose at stationary and exponential phase.

\section{Results of optimization of metal removal capability}

The time course of specific metal removal (q), expressed as mg of metal removed per $\mathrm{g}$ of biomass dry weight, by Nostoc sp. N27P72 and Nostoc sp. FB71 cultivated in media culture containing (10 g/l) maltose, with copper, chromium and nickel in single-metal solutions showed that In single-metal solutions, the kinetics of sorption by the cyanobacterial cultures was always rapid for all the metals tested; the saturation of the metal removal capacity of each strain was achieved within the first $10 \mathrm{~min}$ in the metal solution. The metal affinity of the two Nostoc strains generally decreased in the order $\mathrm{Ni}>\mathrm{Cu}>\mathrm{Cr}$. The specific metal uptake (q) was very high, in particular for Ni (Fig. 2), which generally were removed in larger amounts than $\mathrm{Cu}$ and $\mathrm{Cr}$. Among the strains tested, the highest q values towards Ni was $188.8 \pm 0.14 \mathrm{mg} \mathrm{Ni}$ (g cell dry wt) ${ }^{-1}$ shown by Nostoc sp. N27P72, while the highest values of uptake was $185.5 \pm 0.24$ by Nostoc sp. FB71. In single ion solutions, both Nostoc strains tested showed the lowest affinity for Cr namely $105.65 \pm 0.34104 .5 \pm 0.1 \mathrm{mg}$ metal for Nostoc sp. N27P72 and Nostoc sp. FB71 (g cell dry wt) ${ }^{-1}$ respectively.

\section{Results of optimization of metal removal capability}

Results of optimization of metal removal capability showed that adding maltose in culture media in both strains as carbon source supplementation generally resulted in higher EPS production, protein and neutral sugars content in compression of control. Moreover the amounts of total produced EPSs, protein and neutral sugars content was significantly higher in Nostoc sp. N27P72 in comparison to Nostoc sp. FB71. Exopolysaccharide concentration in medium containing maltose and metal solution of $\mathrm{Ni}(\mathrm{II})$ ) was 4.87 and $3.10 \mu \mathrm{g} / \mathrm{L}$, while it was 2.72 and $1.8 \mu \mathrm{g} / \mathrm{L}$ in control for Nostoc sp. N27P72 and Nostoc sp. FB71 respectively. Protein concentration in medium containing maltose and metal solution of $\mathrm{Ni}(\mathrm{II})$ ) was 4.87 and $3.10 \mathrm{mg} / \mathrm{ml}$, while it was 0.07 and $0.06 \mathrm{mg} / \mathrm{ml}$ in control for Nostoc sp. N27P72 and Nostoc sp. FB71 respectively. Neutral sugars content in medium containing maltose and metal solution of $\mathrm{Ni}(\mathrm{II})$ ) was 5.64 and $5.16 \mu \mathrm{g} / \mathrm{mL}$, while it was 2.85 and $1.74 \mu \mathrm{g} / \mathrm{mL}$ in control for Nostoc sp. N27P72 and Nostoc sp. FB71 respectively. Nickel removal rate was significantly higher in both strains, it means this metal is more absorbed by polysaccharide envelopes. The reason for removing more nickel according to the results of the diagrams is the higher amount 
of EPSs, proteins and neutral sugars content compared to other elements. In fact, More EPS, proteins and neutral sugars content can effectively sequester dissolved metal ions from dilute aqueous solutions (Fig.3).

\section{Results of analysis of functional groups}

Fourier Transformed Infrared (FT-IR) spectroscopy provided useful information about active functional groups that can be used in the determination of polysaccharide composition. So, the FT-IR spectra for both Nostoc sp. N27P72 and Nostoc sp. FB71 cultivated in media culture containing (10 g/l) maltose, with copper, chromium, and nickel in single-metal solutions were examined. Strong stretching vibrations for $\mathrm{OH}$ and weak stretching vibrations for $\mathrm{NH}_{4}^{+}$at $3800 \mathrm{~cm}^{-1}$ can be detected only in Nostoc sp. FB71. The stretching vibration for $\mathrm{NH}$ can be identified around $3779 \mathrm{~cm}^{-1}$ only in Nostoc sp. FB71. In both samples stretching vibration for $\mathrm{OH}$ can be observed at 3400-3440 $\mathrm{cm}^{-1}$. The non-asymmetric and asymmetric stretching vibrations for $\mathrm{CH}$ can be identified at 2854 and $2924 \mathrm{~cm}^{-1}$ only in Nostoc sp. N27P72. The COOH stretching band $\left(1600-1700 \mathrm{~cm}^{-1}\right)$ can see in both samples and didn't change after heavy metal treatment. The $\mathrm{C}-\mathrm{H}$ vibration can be observed at 1380-1400 $\mathrm{cm}^{-1}$ and a peak at $1384 \mathrm{~cm}^{-1}$ correspondings to bending vibration of $\mathrm{CH}_{2}$ can only observe at Nostoc sp. N27P72 in presence of Nicle. A peak at about $1000 \mathrm{~cm}^{-1}$ region is associated with C-O polysaccharide and can not observe at Nostoc sp. FB71 in presence of Nicle. Furthermore, this peak shift to lower wavenumber at Nostoc sp. N27P72 which could be related to polysaccharide conformational changes in both starins. Peaks at 1040 and $1029 \mathrm{~cm}^{-1}$ are correlated to polysaccharides skeletal and C-O-C and C-O groups of the anomeric region. Aliphatic esters can be observed at $1103 \mathrm{~cm}^{-1}$ and this peak is removed due to the interaction of $\mathrm{Ni}, \mathrm{Cr}$, and $\mathrm{Cu}$ to both strains. The $800-900 \mathrm{~cm}^{-1}$ region depicts several vibrational modes corresponding to the type of glycosidic linkages which is removed after treatments of $\mathrm{Cr}$ and $\mathrm{Cu}$ with both strains. Peaks in $840-860 \mathrm{~cm}^{-1}$ region corresponding to a-glucan and $890-910 \mathrm{~cm}^{-1}$ corresponding to $\alpha$ and $\beta$ glycosidase and as can see these peaks were removed in all samples except Ni treatment at Nostoc sp. FB71. Peaks at $600 \mathrm{~cm}^{-1}$ are related to The C-N stretching band $\left(600 \mathrm{~cm}^{-1}\right)$ can see in both sample, but shifted to lower wavenumbers in both strains. Collectively, after treatment of both strains with $\mathrm{Ni}, \mathrm{Cu}$, and $\mathrm{Cr}$ the FT-IR patterns for both strains changed obviously (Fig 4 and 5).

\section{Result of Chemical composition of the lyophilized EPS by GC-MS}

The GC-MS analysis showed cyanobacteria in presence of heave metals change aliphatic compound (2Ethoxyethanol, 3,3-dimethylhexane, Undecane, Dodecane, 2,6,10-trimethyl $\nabla$ Hydroxylamine, 0-decyl

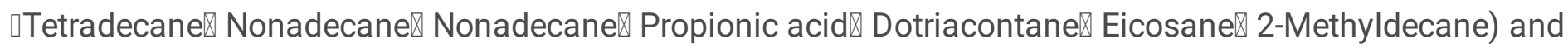
alkanes compounds (Dotriacontane, Dodecane, 2,6,10-trimethyl, 3,3-dimethylhexane, Eicosane) to rich variety of phytochemical compounds which are effective in heavy metal removal. The active compounds with their retention time (RT), molecular formula, molecular weight, nature of the compound, composition percentage and quality in the hexane extract are presented in Tables 1 to 4.

The total ion chromatograms (TICs) of all samples demonstrated a strong signal, large peak capacity, and reproducible retention time, indicating the reliability of metabolomic analysis. However Cyclotrisiloxane retention time was not in the same range for the $\mathrm{Ni}(\mathrm{II})$ and $\mathrm{Cu}(\mathrm{II})$ media culture (11.63 to 23.22), while 1,2Benzenedicarboxylic acid retention time for $\mathrm{Ni}(\mathrm{II})$ and $\mathrm{Cu}(\mathrm{II})$ media culture was in the range of 23.26 to 25.14. 
Moreover $\mathrm{Ni}(\mathrm{II})$ and $\mathrm{Cu}(\mathrm{II})$ culture revealed a high composition of cyclic and Ester compounds (Cyclotrisiloxane, Bis(2-ethylhexyl) phthalate and 1,2-Benzenedicarboxylic acid), while in $\mathrm{Cr}$ (III) cultures there are aldehydes compounds (Decanal, 2,3-dimethylbenzaldehyde), ketones compounds (6-Bromo-2-hexanone), Ester compounds (2-piperidinone), alcoholic compounds (3,5-Hexadien-2-ol, 2-Hexanol, 1,4-pentanediol), ether compounds (2H-pyran, 3,4-dihydro-6-methyl, 2-Butoxyethanol) and cyclic compounds (Cyclotrisiloxane). The strong Ni(II) removal capability of the Nostoc sp. N27P72 was attributed to the abundance of Cyclotrisiloxane (91\%) and 1,2-Benzenedicarboxylic acid (91\%) characterizes by GC-MS (Fig. 6).

\section{Discussion}

The possible use of exopolysaccharide-producing cyanobacteria for the recovery of valuable metals from industrial wash waters seems to be more promising than most of the other microorganisms (Giner-Lamia et al., 2016; Ni et al., 2019; El Bestawy., 2019; El-Sheekh et al., 2005). The use of cyanobacterial EPS for biotechnological applications depends on the identification of culture parameters that influence the maximum production of the EPS (Chug and Mathur., 2013; Li et al., 2001; Bhunia et al., 2018). Factors such as the amounts of C:N ratio, as well as growth parameters such as light intensity, salinity and temperature have been largely disregarded, and very few exhaustive studies on factors influencing the production of cyanobacterial EPS are available in the literature (Pereira et al., 2009). Though, several elements that can stimulus EPS production, especilly $\mathrm{pH}$, dilution rate, growth phase, presence/absence of magnesium, calcium, potassium and heavy metals, as well as the addition of glycoxylate, glucose, citrate, acetate, valerate and EDTA have been sporadically studied (Pereira et al., 2009). Moreover, the responses of cyanobacteria to changes in culture conditions appear to be frequently strain-dependent, making the optimization of EPS production even more difficult (Floutya et al., 2019). It was suggested that some additives, including amino acids, vitamins and precursors, may also play an important role in EPS production during the process of cyanobacteria (Pereira et al., 2011).

In this article, we investigated the effect of adding four different sugars in the culture medium (glucose, maltose, lactose, and sucrose) as carbohydrate source and its effect on the amount of EPS and cell dry weight in two strains of Nostoc was investigated. The results of the present investigation indicated that the optimal medium for EPS production by the isolated Nostoc sp. N27P72 strain was boosted by maltose supplementation. Previous studies on several bacterial EPS production reported that amino acids and precursor's supplements showed stimulating effect on bacterial growth and EPS synthesis, while others demonstrated that neither additional carbohydrates nor amino acids supplementation affect the EPS level (Maalej et al. 2015). Moreover, among different nature of carbon sources, carbohydrate sugars are the preferred ones for EPS production. In this study, maltose were found to be the most efficient carbon sources.

Unfortunately, large amounts of toxic elements, especially heavy metals which are harmful to human beings, are daily released in nature through human and industrial activities (Tchounwou et al. 2012).

Exopolysaccharides are well suggested as surface-active mixtures for the exclusionof heavy metal pollution. Consequently, to find out microbial EPS with decent metal adsorption selectivity may be very valuable for building up processes aiming to pick up valuable metals from industrial wastewater. Bearing this in mind, we studied supplemented media culture as an additional sugar source exopolysaccharide to evaluation of its efficiency to adsorb various toxic heavy metals ( $\mathrm{Cu}, \mathrm{Ni}$ and $\mathrm{Cr}$ ) (Mohite et al., 2017). We found that using 
maltose as carbon sources was shown to produce a higher amount of EPS, protein and neutral sugars content and it could be a reason for high ability of metal absorbance. This statements has been underlined by Wong and Tam (1984) who stated that algal cells cultivated in the media with very high metal contents also gathered higher metal contents. In spite of this, in few cases, the metal uptake was independent on the external metal concentration, this point was coincided with the conclusion of Wetton et al. (1976). In case of $N$. muscorum grown in wastewater, high concentrations of $\mathrm{Cu}$ and $\mathrm{Mn}$ did not affect the growth of the microorganism but promote its growth. This may be because of the resistance of the cyanobacterium to $\mathrm{Cu}$ and $\mathrm{Mn}$ in addiotion to the occurrence of high content of organic matter, which may detoxify $\mathrm{Cu}$ and $\mathrm{Mn}$ effects (El-Enany and Issa, 2000).

In fact, the quantity and compactness of different kind of carbohydrates can help to sort the polysaccharidic layer surrounding the cells which can also prevent direct contact between the cells and toxic heavy metals. Actually, it was recently suggested that the high viscosity of the cultures, due to the solubilization in the culture medium of large amounts of a high molecular mass RPS, delayed the free diffusion of copper ions into the media culture (Micheletti et al., 2008). the presence of negatively charged polysaccharidic layers surrounding cyanobacterial cells such as uronic acids, sulphate and ketal-linked pyruvate groups may play an important role in the sequestration of metal cations, and in forrming an environment improved in those metals that are crucial for cell growth but are existing at very low concentrations in some environments (Pereira et al., 2009).

We found that strain of Nostoc sp. N27P72 that is isolated from lime stones of Khuzestan province have many features which include high amount of EPS and high tolerance to drought and high density of light that make it ideal candidate for the selective removal and concentration of heavy metals, compared to aquatic strain. Actully, in all of the possible systems in which cyanobacteria are involved, the synthesis of EPSs provides a structurally-stable and hydrated microenvironment, as well as a putative physical defensive role against some risky factors, both chemical and physical, representing a boundary between cells and the immediate outer environment, and preserve the cells from toxic heavy metal (Rossi and Philippis., 2015).

The experiments, showed that Nostoc sp. N27P72 biomass is characterized by the best efficiency in metal removal, with a qmax (maximum amount of nickel removed per biomass unit) of $188.8 \pm 0.14 \mathrm{mg} \mathrm{Ni}$ (g cell dry wt) ${ }^{-1}$ nickel removed in comparison with the value of $185.5 \pm 0.24 \mathrm{mg} \mathrm{Ni}^{(\mathrm{g} \text { cell dry wt) }}{ }^{-1}$ of Nostoc sp. FB71 biomass. Thus, the metal uptake capacity of EPS under study (especially for nickel) is of great interest regarding other biosorbent efficiencies and the lowest affinity for $\mathrm{Cr}$. Our results contradicted with the result of Chan et al. (1991) who found that the removal of Ni from the mixture of $90 \%$ electroplating effluent and $10 \%$ raw sewage by two species of Chlorella was comparatively low (below 20\%). While Kazy et al. (2002) reported that EPS production by a copper-resistant isolate of Pseudomonas aeruginosa was considerably higher than its copper sensitive counterpart. Moreover, Ozturk and Aslim., 2008 found $\mathrm{Cr}(\mathrm{VI})$ is an important stress factor that increases EPS concentration in cyanobacteria.

Interestingly, using optimized culture conditions increases the yield of the Nostoc sp. N27P72 EPS, thus improving the chances of its commercial scale production and making it more suitable for special applications, such as the environmental industry. However finding a general pattern for the special effects of metals on EPS synthesis is very hard. It is thought that the effects on EPS synthesis are metal-specific. In

Page $10 / 24$ 
some cases, a shortage of $\mathrm{Mg}^{2+}$ and $\mathrm{Ca}^{2+}$ elicited production, whereas there were no effects in other cases. The increase in EPS synthesis appears to develop the resistance to toxic metals. A study carried out by Ozturk and Aslim [9] showed that Chroococcus and Synechocystis strains resistant to $\mathrm{Cr}(\mathrm{VI})$ created larger EPS amounts compared to the $\mathrm{Cr}(\mathrm{VI})$-sensible isolates. It is promissing that a greater EPS concentration inspired by the metal played a role in increasing its immobilization, as suggested by Pereira et al. 2013. Though, it was lately reported that in Cyanothece sp. CCY 0110, the existence of heavy metals expressively affected its protein profile but did not improve the amount of RPS released by the cells (Mota et al. 2016).

Due to the presence of negatively charged groups ,primarily carboxyl group they have also been shown to have good sorbent capacity towards positively charged metal ions (Mathlouthi and Koenig, 1987). (GómezOrdóñez and Rupérez, 2011) (Ponnuswamy et al., 2013) (Leal et al., 2008). (Mishra and Jha, 2009). Among the parameters that strongly affect the metal uptake capacity of biopolymers is the metal affinity to their functional groups (Delattre et al., 2016). Shuhong et al. (2014) reported the implication of O-H, C=O, C-O-C and $\mathrm{C}=0-\mathrm{C}$ groups of the EPS in the binding of $\mathrm{Cu}^{2+}, \mathrm{pb}^{2+}$ and $\mathrm{Cr}^{6+}$ ions.

GC-MS is extensively used method for metabolomics research to date, particularly for enabling the identification and quantification of the metabolites involved in the central pathways of primary metabolism such as amino acids, sugar alcohols, sugars, organic acids and polyamines. In this study, the metabolite profiling analysis in two Nostoc species after $24 \mathrm{~h}$ exposure to $\mathrm{Cu}(\mathrm{II}), \mathrm{Cr}(\mathrm{III})$ and $\mathrm{Ni}(\mathrm{II})$ has been performed using GC-MS analysis. The GC-MS analysis of extract of Ni(II) and Cu(II) Nostoc sp. N27P72 revealed cyclic and ester compounds (Cyclotrisiloxane, Bis(2-ethylhexyl) phthalate and 1,2-Benzenedicarboxylic acid), in comparison to control. These compounds in the EPS are recorded as absorption agent. Wu et al (2006) attributed the cytotoxicity effects of fatty acids to their ability to increase the membrane permeability leading to membrane damage. Mundt et al 2003 , suggested that fatty acids produced by cyanobacteria as a defense mechanism against other microorganisms might be able to change the permeability of the cell membrane Through interacting with proteins and lipids of the membrane, inhibiting special enzymes or by a layer around the cells. Presence compounds of Benzene derivatives in Ni and Cu cultures may be related to absorption compounds to remove the metal, actually it has been previously been shown that some benzene inhibited bketoacyl-acyl carrier protein synthase III, a condensing enzyme that initiates fatty acid biosynthesis in most cyanobacteria, leading to absorption activity of metal. Furthermore, the cytotoxic activity of the pure compound 1, 2- benzene dicarboxylic acid, mono 2- ethylhexyl ester (DMEHE) from marine derived actinomycete Streptomyces sp. VITSJK8 was examined against mouse embryonic fibroblast (NIH 3T3) and human keratinocyte (HaCaT) normal cell lines, human hepatocellular liver carcinoma (HepG 2) and human breast adenocarcinoma (MCF-7) cell lines by using MTT assay (Krishnan et al., 2014). 1,2-

Benzenedicarboxylic acid, bis(2-methyl propyl) ester was recorded by Alghamdi et I., 2018 as plasticizer and has light and heat stability. The antibacterial properties of olive leaves extract is suspected to be associated with the high cyclotrisiloxane hexamethyl content, which has been tested by Keskin e al., 2012. lastly, as compared to solid wastes created from old approach used for the heavy metal removal, polysaccharides are natural, nontoxic and biodegradable polymers, thus reducing their polluting effects and making them attractive for potential use as metal-absorbent safe materials. In conclusion, the strain Nostoc sp. N27P72 may be a suitable candidate for mass production of an ecologically attractive EPS with a potential for use in the bioremediation field. 


\section{Conclusion}

From the above described investigational results, it seems obvious that the EPS plays an crucial role in protecting from harmful toxic heavy metal. However, in spite of the large number of studies claiming this role, only a few of them directly investigated the modification of metal removal capability by cyanobacteria under mixotrophic condition. In the present study, the highest EPS production efficiency was found in cultures supplemented by maltose and biomass of Nostoc sp. N27P72 possesses a high affinity and a high specific uptake for nickel, comparable with the best performances shown by other microbial biomass, and suggest the possibility to use Nostoc sp. N27P72 for the bioremoval of heavy metals from polluted water bodies. The FTIR spectra showed that treatment of $\mathrm{Ni}$ with both strains made obvious changes in functional groups of polysaccharids and linkages. Cyclotrisiloxane and 1,2-Benzenedicarboxylic acid, major constituent of Nostoc sp. N27P72 in this study, metal removal capability of Nostoc sp. N27P72 extract is suspected to be associated with the high Cyclotrisiloxane and 1,2-Benzenedicarboxylic acid content. Lastly, although the key elements controlling the production of the cyanobacterial EPS have been recognized, invlusive strain-specific studies taking into account the interaction between the variables to know the system reaction to changes, are still missing. This needs a better facts of the genes and metabolic paths complicated in the production of EPS in cyanobacteria.

\section{Declarations}

Conflict of interest The authors declare no competing financial interest

Funding No funding was received for this work

Ethics approval Not applicable

Availability of data and material Not applicable

Code availability Not applicable

Informed consent No human participants were involved in this study

Consent to participate Not applicable

Consent for publication Not applicable

Acknowledgements Not applicable

Author Contribution Bahareh Nowruzi supervised and proof-read the manuscript, Elham Ghorbani, Mssomeh NejadAli and Azadeh Hekmat edited and proof-read.

\section{References}

Alghamdi S, Migdadi H, Khan M, El-Harty EH, Ammar M, Farooq M, Afzal M. Phytochemical Profiling of Soybean (Glycine max (L.) Merr.) Genotypes Using GC-MS Analysis. Phytochemicals-Source of Antioxidants and Role in Disease Prevention. 2018 Nov 7. 
Anjana K, Kaushik A, Kiran B, Nisha R. Biosorption of $\mathrm{Cr}(\mathrm{VI})$ by immobilized biomass of two indigenous strains of cyanobacteria isolated from metal contaminated soil. Journal of Hazardous Materials. 2007 Sep 5;148(1-2):383-6.

Bhunia B, Uday US, Oinam G, Mondal A, Bandyopadhyay TK, Tiwari ON. Characterization, genetic regulation and production of cyanobacterial exopolysaccharides and its applicability for heavy metal removal. Carbohydrate polymers. 2018 Jan 1;179:228-43.

Cepoi L, Zinicovscaia I, Chiriac T, Rudi L, Yushin N, Miscu V. Silver and gold ions recovery from batch systems using Spirulina platensis biomass. Ecological Chemistry and Engineering S. 2019 Jun 1;26(2):229-40.

Chan, S.S., Chow, H., Wong, M.H., 1991. Microalgae as bioabsorbents for treating mixture of electroplating and sewage effluent. Biomed. Environ. Sci. 4, 250-261.

Chug R, Mathur S. Extracellular Polymeric Substances from Cyanobacteria: Characteristics, Isolation and Biotechnological Applications-A. International Journal of Engineering, Science and Technology. 2013;3:49-53.

Delattre C, Pierre G, Laroche C, Michaud P. Production, extraction and characterization of microalgal and cyanobacterial exopolysaccharides. Biotechnology advances. 2016 Nov 15;34(7):1159-79.

De Philippis, R., Sili, C., Paperi, R and Vincenzini, M. 2001. Exopolysaccharide-producing cyanobacteria and their possible exploitation: a review. J APPL PHYCOL, 13: 293-299.

De Philippis, R., Faraloni, C., Margheri, M. C., Sili, C., Herdman, M and Vincenzini, M. 2000. Morphological and biochemical characterization of the extracellular investments of polysaccharide-producing Nostoc strains from the Pasteur Culture Collection. WORLD J MICROBIOL BIOTECHNOL, 16: 655-661.

De Philippis R, Paperi R, Sili C, Vincenzini M. Assessment of the metal removal capability of two capsulated cyanobacteria, Cyanospira capsulata and Nostoc PCC7936. Journal of Applied Phycology. 2003 Mar 1;15(23):155-61.

Devi YM, Mehta SK. Changes in antioxidative enzymes of cyanobacterium Nostoc muscorum under copper (Cu2+) stress. Sci. Vision. 2014;14:207-14.

El Bestawy E. Efficiency of immobilized cyanobacteria in heavy metals removal from industrial effluents. DESALINATION AND WATER TREATMENT. 2019 Aug 1;159:66-78.

El-Enany, A.E., Issa, A.A., 2000. Cyanobacteria as a biosorbent of heavy metals in sewage water. Environ. Toxicol. Pharmacol. 8, 95- 101.

El-Sheekh MM, El-Shouny WA, Osman ME, El-Gammal EW. Growth and heavy metals removal efficiency of Nostoc muscorum and Anabaena subcylindrica in sewage and industrial wastewater effluents. Environmental Toxicology and Pharmacology. 2005 Feb 1;19(2):357-65.

Essa AM, Mostafa SS. HEAVY METALS BIOMINERALIZATION BY SOME CYANOBACTERIAL ISOLATES. Egyptian Journal of Botany. 2012;52(1):145-57. 
Farooqui A, Suhail S, Zeeshan M. Cadmium induced oxidative stress and biochemical responses in cyanobacterium Nostoc muscorum. Russian Journal of Plant Physiology. 2017 Jan 1;64(1):124-32.

Floutya R, El-Khourya J, Maatouka E, El-Samrania A. Optimization of $\mathrm{Cu}$ and Pb biosorption by Aphanizomenon ovalisporum using Taguchi approach: kinetics and equilibrium modeling. Desalination and Water Treatment. 2019 Jul 1;155:259-71.

Giner-Lamia J, Pereira SB, Bovea-Marco M, Futschik ME, Tamagnini P, Oliveira P. Extracellular proteins: novel key components of metal resistance in cyanobacteria?. Frontiers in microbiology. 2016 Jun 7;7:878.

Gupta P, Diwan B. Bacterial exopolysaccharide mediated heavy metal removal: a review on biosynthesis, mechanism and remediation strategies. Biotechnology Reports. 2017 Mar 1;13:58-71.

Helm, R. F., Huang, Z., Edwards, D., Leeson, H., Peery, W and Potts, M. 2000. Structural characterization of the released polysaccharide of desiccation-tolerent Nostoc commune DRH-1. J BACTERIOL, 182: 974-982.

Kazy SK, Sar P, Singh SP, Sen AK, D'souza S. Extracellular polysaccharides of a copper-sensitive and a copperresistant Pseudomonas aeruginosa strain: synthesis, chemical nature and copper binding. World Journal of Microbiology and Biotechnology. 2002 Aug 1;18(6):583-8.

Keskin D, Ceyhan N, Ugur A, Dbeys AD. Antimicrobial activity and chemical constitutions of West Anatolian olive (Olea europaea L.) leaves. Journal of Food, Agriculture \& Environment. 2012 Apr 1;10(2):99-102.

Klock, J. H., Wieland, A., Seifert, R and Michaelis, W. 2007. Extracellular polymeric substances (EPS) from cyanobacterial mats: characterisation and isolation method optimization. MAR BIOL, 152: 1077-1085.

Krishnan K, Mani A, Jasmine S. Cytotoxic activity of bioactive compound 1, 2-benzene dicarboxylic acid, mono 2-ethylhexyl ester extracted from a marine derived Streptomyces sp. VITSJK8. International journal of molecular and cellular medicine. 2014;3(4):246.

Kumaran NS, Sundaramanicam A, Bragadeeswaran S. Adsorption studies on heavy metals by isolated cyanobacterial strain (nostoc sp.) from uppanar estuarine water, southeast coast of India. Journal of Applied Sciences Research. 2011;7(11):1609-15.

Kumar, A. S., Mody, K and Jha, B. 2007. Bacterial exopolysaccharides - a perception, J BASIC MICROB, 47: 103-117.

Li P, Harding SE, Liu Z. Cyanobacterial exopolysaccharides: their nature and potential biotechnological applications. Biotechnology and Genetic Engineering Reviews. 2001 Jul 1;18(1):375-404.

Liu, L., Jokela, J., Wahlsten, M., Nowruzi, B., Permi, P., Zhang, Y.Z., Xhaard, H., Fewer, D.P. and Sivonen, K., 2014. Nostosins, trypsin inhibitors isolated from the terrestrial cyanobacterium Nostoc sp. strain FSN. J Nat Prod. 77(8), pp.1784-1790.

Lowry, O. H., Rosebrough, N. J., Farr, A. L and Randall, R. J. 1951. Protein measurement with the Folin phenol reagent. J. BIOL. CHEM, 193: 265-/275. 
Maalej H, Hmidet N, Boisset C, Buon L, Heyraud A, Nasri M. Optimization of exopolysaccharide production from $P$ seudomonas stutzeri AS 22 and examination of its metal-binding abilities. Journal of applied microbiology. 2015 Feb;118(2):356-67.

Micheletti E, Colica G, Viti C, Tamagnini P, De Philippis R. Selectivity in the heavy metal removal by exopolysaccharide-producing cyanobacteria. Journal of applied microbiology. 2008 Jul;105(1):88-94.

Micheletti E, Pereira S, Mannelli F, Moradas-Ferreira P, Tamagnini P, De Philippis R. Sheathless mutant of cyanobacterium Gloeothece sp. strain PCC 6909 with increased capacity to remove copper ions from aqueous solutions. Applied and environmental microbiology. 2008 May 1;74(9):2797-804.

Mohite BV, Koli SH, Narkhede CP, Patil SN, Patil SV. Prospective of microbial exopolysaccharide for heavy metal exclusion. Applied biochemistry and biotechnology. 2017 Oct 1;183(2):582-600.

Mota R, Rossi F, Andrenelli L, Pereira SB, De Philippis R, Tamagnini P. Released polysaccharides (RPS) from Cyanothece sp. CCY 0110 as biosorbent for heavy metals bioremediation: interactions between metals and RPS binding sites. Applied microbiology and biotechnology. 2016 Sep 1;100(17):7765-75.

Mota R, Pereira SB, Meazzini M, Fernandes R, Santos A, Evans CA, De Philippis R, Wright PC, Tamagnini P. Effects of heavy metals on Cyanothece sp. CCY 0110 growth, extracellular polymeric substances (EPS) production, ultrastructure and protein profiles. Journal of proteomics. 2015 Apr 29;120:75-94.

Mundt, S. S. Kreitlow and R. Jansen, 2003. Fatty acids with antibacterial activity from the cyanobacterium Oscillatoria redekei HUB 051. J. Applied Phycol., 15: 263-267.

Ni L, Gu G, Rong S, Hu L, Wang P, Li S, Li D, Liu X, Wang Y, Acharya K. Effects of cyanobacteria decomposition on the remobilization and ecological risk of heavy metals in Taihu Lake. Environmental Science and Pollution Research. 2019 Dec 1;26(35):35860-70.

Nowruzi B, Khavari-Nejad RA, Sivonen K, Kazemi B, Najafi F, Nejadsattari T. Optimization of cultivation conditions to maximize extracellular investments of two Nostoc strains. Algological Studies. 2013 May $1 ; 142(1): 63-76$.

Otero, A and Vincenzini, M. 2003. Extracellular polysaccharide synthesis by Nostoc strains affected by $\mathrm{N}$ source and light intensity. J. BIOTECHNOL, 102: 143-152.

Ozturk S, Aslim B. Relationship between chromium (VI) resistance and extracellular polymeric substances (EPS) concentration by some cyanobacterial isolates. Environmental Science and Pollution Research. 2008 Sep 1;15(6):478-80.

Pereira, S., Zille, A., Micheletti, E., Moradas-FErreira, P., Philippis, E., Roberto, D. E and Tamagnini, P. 2009. Complexity of cyanobacterial exopolysaccharides: composition, structures, inducing factors and putative genes involved in their biosynthesis and assembly. FEMS MICROBIOL REV, 33: 917-941.

Pereira S, Zille A, Micheletti E, Moradas-Ferreira P, De Philippis R, Tamagnini P. Complexity of cyanobacterial exopolysaccharides: composition, structures, inducing factors and putative genes involved in their 
biosynthesis and assembly. FEMS microbiology reviews. 2009 Sep 1;33(5):917-41.

Pereira SB, Mota R, Santos CL, De Philippis R, Tamagnini P. Assembly and export of extracellular polymeric substances (EPS) in cyanobacteria: a phylogenomic approach. InAdvances in Botanical Research 2013 Jan 1 (Vol. 65, pp. 235-279). Academic Press.

Pereira SB, Mota R, Vieira CP, Vieira J, Tamagnini P. Phylum-wide analysis of genes/proteins related to the last steps of assembly and export of extracellular polymeric substances (EPS) in cyanobacteria. Scientific reports. 2015 Oct 6;5:14835.

Pereira S, Micheletti E, Zille A, Santos A, Moradas-Ferreira P, Tamagnini P, De Philippis R. Using extracellular polymeric substances (EPS)-producing cyanobacteria for the bioremediation of heavy metals: do cations compete for the EPS functional groups and also accumulate inside the cell?. Microbiology. 2011 Feb $1 ; 157(2): 451-8$.

Principe MV, Permigiani IS, Della Vedova MC, Petenatti E, Pacheco P, Gil RA. Bioaccessibility studies of Fe, Cu and $\mathrm{Zn}$ from Spirulina dietary supplements with different excipient composition and dosage form. Journal of Pharmacy \& Pharmacognosy Research. 2020;8(5):422-33.

Rippka, R., Derulles, J., Watrerbury, J. B., Herdman, M and Stanier, R. Y. 1979. Generic assignments, strain histories and properties of pure cultures of cyanobacteria. J GEN MICROBIOL, 111: 1-61.

Rossi F, De Philippis R. Role of cyanobacterial exopolysaccharides in phototrophic biofilms and in complex microbial mats. Life. 2015 Jun;5(2):1218-38.

Sampathkumar Y, Halith AM. GCMS Determination of Anticancer, Anti inflammatory and Anti bacterial compounds from salt tolerance Microalgae (Lyngbya sp. Nostoc sp. and Phormidium sp.) Isolated from Marakkanam Salt Pan, Tamil Nadu, India.

Sardari RR, Kulcinskaja E, Ron EY, Björnsdóttir S, Friðjónsson ÓH, Hreggviðsson GÓ, Karlsson EN. Evaluation of the production of exopolysaccharides by two strains of the thermophilic bacterium Rhodothermus marinus. Carbohydrate polymers. 2017 Jan 20;156:1-8.

Suresh Kumar A, Mody K, Jha B. Bacterial exopolysaccharides-a perception. Journal of basic microbiology. 2007 Apr;47(2):103-17.

Tchounwou PB, Yedjou CG, Patlolla AK, Sutton DJ. Heavy metal toxicity and the environment. InMolecular, clinical and environmental toxicology 2012 (pp. 133-164). Springer, Basel.

Wetton, M., Lorch, D.W., Weber, A., 1976. Arch. Hydrobiol. 77, 267- 276. Cited in Elliot Shubert, L., 1984. Algae as Ecological Indictors. Academic Press, London

Wong, M.H., Tam, F.Y., 1984. Sewage sludge for cultivating freshwater algae and the fate of heavy metals at higher trophic organisms. Arch. Hydrobiol. 100, 287-318. 
Wu JT, Chiang YR, Huang WY, Jane WN. Cytotoxic effects of free fatty acids on phytoplankton algae and cyanobacteria. Aquatic Toxicology. 2006 Dec 30;80(4):338-45.

Yoshimura, H., Kotake, T., Aohara, T., Tsumuraya, Y., Ikeuchi, M and Ohmori, M. 2011. The role of extracellular polysaccharides produced by the terrestrial cyanobacterium Nostoc sp. Strain HK-01 in NaCl tolerance. J APPL PHYCOL, 24: 237-243.

Zinicovscaia I, Rudi L, Valuta A, Cepoi L, Vergel K, Frontasyeva MV, Safonov A, Wells M, Grozdov D. Biochemical changes in Nostoc linckia associated with selenium nanoparticles biosynthesis. Ecological Chemistry and Engineering S. 2016 Dec 1;23(4):559-69.

\section{Tables}

Table 1: Chemical composition of Nostoc sp. N27P72 (control) extracts as revealed by gas chromatography mass spectrophotometry (GC-MS).

\begin{tabular}{|llllll|}
\hline $\begin{array}{l}\text { Area } \\
\%\end{array}$ & $\begin{array}{l}\text { Nature of the } \\
\text { compound }\end{array}$ & $\begin{array}{l}\text { RT } \\
(\text { Mins })\end{array}$ & $\begin{array}{l}\text { Molecular } \\
\text { weight }\end{array}$ & $\begin{array}{l}\text { Molecular } \\
\text { Formula }\end{array}$ & Name of Compound \\
\hline $83 \%$ & hydroxyether & 8.77 & 90.12 & $\mathrm{C}_{4} \mathrm{H}_{10} \mathrm{O}_{2}$ & 2-Ethoxyethanol \\
\hline $96 \%$ & Phenolic ester & 26.29 & 278.5 & $\mathrm{C}_{17} \mathrm{H}_{30} \mathrm{OSi}$ & $\begin{array}{l}\text { Phenol, 2,4-bis-(1,1- } \\
\text { dimethylethyl) }\end{array}$ \\
\hline $64 \%$ & alkane & 26.41 & 212.41 & $\mathrm{C}_{15} \mathrm{H}_{32}$ & Dodecane, 2,6,10-trimethyl \\
\hline $40 \%$ & alkane & 27.15 & 114.23 & $\mathrm{C}_{8} \mathrm{H}_{18}$ & 3,3-dimethylhexane \\
\hline $78 \%$ & alkane & 28 & 156.31 & $\mathrm{C}_{11} \mathrm{H}_{24}$ & Undecane \\
\hline $78 \%$ & alkane & 29.75 & 173.2957 & $\mathrm{C}_{10} \mathrm{H}_{23}$ & Hydroxylamine, O-decyl \\
\hline $59 \%$ & alkane & 29.95 & 198.39 & $\mathrm{C}_{14} \mathrm{H}_{30}$ & Tetradecane \\
\hline $83 \%$ & alkane hydrocarbon & 30.20 & 268.5 & $\mathrm{C}_{19} \mathrm{H}_{40}$ & Nonadecane \\
\hline $35 \%$ & Organic acid & 30.66 & 74.08 & $\mathrm{CH}_{3} \mathrm{CH}_{2} \mathrm{CO}_{2} \mathrm{H}$ & Propionic acid \\
\hline $64 \%$ & alkane & 30.68 & 450.8664 & $\mathrm{C}_{32} \mathrm{H}_{66}$ & Dotriacontane \\
\hline $53 \%$ & alkane & 31.69 & 282.5 & $\mathrm{C}_{20} \mathrm{H}_{42}$ & Eicosane \\
\hline
\end{tabular}

Table 2: Chemical composition of Nostoc sp. N27P72 (Ni(II)) extracts as revealed by gas chromatography mass spectrophotometry (GC-MS). 


\begin{tabular}{|c|c|c|c|c|c|}
\hline $\begin{array}{l}\text { Area } \\
\%\end{array}$ & RT & $\begin{array}{l}\text { Nature of the } \\
\text { compound }\end{array}$ & $\begin{array}{l}\text { Molecular } \\
\text { weight }\end{array}$ & $\begin{array}{l}\text { Molecular } \\
\text { Formula }\end{array}$ & Name of Compound \\
\hline $49 \%$ & 11.55 & $\begin{array}{l}\text { six-membered } \\
\text { heterocyclic }\end{array}$ & 82.1 & $\mathrm{C}_{5} \mathrm{H}_{6} \mathrm{O}$ & pyran \\
\hline $90 \%$ & 12.02 & $\begin{array}{l}\text { Heterocyclic } \\
\text { compound }\end{array}$ & 138.3 & $\mathrm{H}_{6} \mathrm{O}_{3} \mathrm{Si}_{3}$ & Cyclotrisiloxane \\
\hline $91 \%$ & 15.97 & $\begin{array}{l}\text { Heterocyclic } \\
\text { compound }\end{array}$ & 138.3 & $\mathrm{H}_{6} \mathrm{O}_{3} \mathrm{Si}_{3}$ & Cyclotrisiloxane \\
\hline $91 \%$ & 19.62 & $\begin{array}{l}\text { Heterocyclic } \\
\text { compound }\end{array}$ & 84.12 & $\mathrm{C}_{5} \mathrm{H}_{8} \mathrm{O}$ & Cyclotrisiloxane \\
\hline $91 \%$ & 23.22 & $\begin{array}{l}\text { Heterocyclic } \\
\text { compound }\end{array}$ & 138.3 & $\mathrm{H}_{6} \mathrm{O}_{3} \mathrm{Si}_{3}$ & Cyclotrisiloxane \\
\hline $90 \%$ & 23.51 & $\begin{array}{l}\text { Quinoline } \\
\text { Ester }\end{array}$ & 166.1308 & $\mathrm{C} 8 \mathrm{H} 6 \mathrm{O} 4$ & $\begin{array}{l}\text { 1,2-Benzenedicarboxylic } \\
\text { acid }\end{array}$ \\
\hline $91 \%$ & 24.01 & $\begin{array}{l}\text { Quinoline } \\
\text { Ester }\end{array}$ & 166.1308 & $\mathrm{C} 8 \mathrm{H} 604$ & $\begin{array}{l}\text { 1,2-Benzenedicarboxylic } \\
\text { acid }\end{array}$ \\
\hline $91 \%$ & 24.13 & $\begin{array}{l}\text { Quinoline } \\
\text { Ester }\end{array}$ & 166.1308 & $\mathrm{C} 8 \mathrm{H} 6 \mathrm{O} 4$ & $\begin{array}{l}\text { 1,2-Benzenedicarboxylic } \\
\text { acid }\end{array}$ \\
\hline $91 \%$ & 24.35 & $\begin{array}{l}\text { Quinoline } \\
\text { Ester }\end{array}$ & 166.1308 & $\mathrm{C} 8 \mathrm{H} 604$ & $\begin{array}{l}\text { 1,2-Benzenedicarboxylic } \\
\text { acid }\end{array}$ \\
\hline $91 \%$ & 24.55 & $\begin{array}{l}\text { Quinoline } \\
\text { Ester }\end{array}$ & 166.1308 & $\mathrm{C} 8 \mathrm{H} 604$ & $\begin{array}{l}\text { 1,2-Benzenedicarboxylic } \\
\text { acid }\end{array}$ \\
\hline $91 \%$ & 24.63 & $\begin{array}{l}\text { Quinoline } \\
\text { Ester }\end{array}$ & 166.1308 & $\mathrm{C} 8 \mathrm{H} 6 \mathrm{O} 4$ & $\begin{array}{l}\text { 1,2-Benzenedicarboxylic } \\
\text { acid }\end{array}$ \\
\hline $91 \%$ & 25.04 & $\begin{array}{l}\text { Quinoline } \\
\text { Ester }\end{array}$ & 166.1308 & $\mathrm{C} 8 \mathrm{H} 604$ & $\begin{array}{l}\text { 1,2-Benzenedicarboxylic } \\
\text { acid }\end{array}$ \\
\hline $91 \%$ & 25.14 & $\begin{array}{l}\text { Quinoline } \\
\text { Ester }\end{array}$ & 166.1308 & $\mathrm{C} 8 \mathrm{H} 6 \mathrm{O} 4$ & $\begin{array}{l}\text { 1,2-Benzenedicarboxylic } \\
\text { acid }\end{array}$ \\
\hline
\end{tabular}

Table 3: Chemical composition of Nostoc sp. N27P72 (Cr(III)) extracts as revealed by gas chromatography mass spectrophotometry (GC-MS). 


\begin{tabular}{|c|c|c|c|c|c|}
\hline $\begin{array}{l}\text { Area } \\
\%\end{array}$ & RT & $\begin{array}{l}\text { Molecular } \\
\text { weight }\end{array}$ & $\begin{array}{l}\text { Nature of } \\
\text { the } \\
\text { compound }\end{array}$ & $\begin{array}{l}\text { Molecular } \\
\text { Formula }\end{array}$ & Name of Compound \\
\hline $37 \%$ & 10.5 & 327.25 & ester & $\mathrm{C}_{16} \mathrm{H}_{10} \mathrm{~F}_{5} \mathrm{NO}$ & Tranylcypromine, pentafluorobenzoyl \\
\hline $43 \%$ & 10.85 & 102.17 & $\begin{array}{l}\text { Six carbon } \\
\text { alcohol }\end{array}$ & $\mathrm{C} 6 \mathrm{H} 140$ & 2-Hexanol \\
\hline $64 \%$ & 11.73 & 138.3 & $\begin{array}{l}\text { Heterocyclic } \\
\text { compound }\end{array}$ & $\mathrm{H}_{6} \mathrm{O}_{3} \mathrm{Si}_{3}$ & Cyclotrisiloxane \\
\hline $87 \%$ & 11.83 & 138.3 & $\begin{array}{l}\text { Heterocyclic } \\
\text { compound }\end{array}$ & $\mathrm{H}_{6} \mathrm{O}_{3} \mathrm{Si}_{3}$ & Cyclotrisiloxane \\
\hline $60 \%$ & 12.70 & 98.14 & enol ether. & $\mathrm{C}_{6} \mathrm{H}_{10} \mathrm{O}$ & 2H-pyran, 3,4-dihydro-6-methyl \\
\hline $72 \%$ & 13.35 & 118.17 & glycol ether & $\mathrm{C}_{6} \mathrm{H}_{14} \mathrm{O}_{2}$ & 2-Butoxyethanol \\
\hline $40 \%$ & 15.12 & 104.15 & diol & $\mathrm{C}_{5} \mathrm{H}_{12} \mathrm{O}_{2}$ & 1,4-pentanediol \\
\hline $91 \%$ & 15.97 & 482.8 & $\begin{array}{l}\text { Heterocyclic } \\
\text { compound }\end{array}$ & $\mathrm{C}_{23} \mathrm{H}_{30} \mathrm{O}_{4} \mathrm{Si}_{4}$ & Cyclotetrasiloxane \\
\hline $9 \%$ & 16.29 & 96.13 & alcohol & $\mathrm{C}_{6} \mathrm{H}_{10} \mathrm{O}$ & 3,5-Hexadien-2-ol \\
\hline $9 \%$ & 18.40 & 179.05 & ketone & $\mathrm{C}_{6} \mathrm{H}_{11} \mathrm{BrO}$ & 6-Bromo-2-hexanone \\
\hline $9 \%$ & 18.55 & 99.13 & lactam & $\mathrm{C}_{5} \mathrm{H}_{9} \mathrm{NO}$ & 2-piperidinone \\
\hline $91 \%$ & 19.63 & 230.5 & silicone & $\mathrm{H}_{10} \mathrm{O}_{5} \mathrm{Si}_{5}$ & Cyclopentasiloxane \\
\hline 20.5 & 20.5 & 166.17 & aldehyde & $(\mathrm{CH} 30) 2 \mathrm{C} 6 \mathrm{H} 3 \mathrm{CHO}$ & 2,3-dimethylbenzaldehyde \\
\hline 20.64 & 20.64 & 118.09 & $\begin{array}{l}\text { Organic } \\
\text { acid }\end{array}$ & $\mathrm{C}_{4} \mathrm{H}_{6} \mathrm{O}_{4}$ & Succinic acid \\
\hline 23.04 & 23.04 & 156.26 & aldehyde & $\mathrm{C}_{10} \mathrm{H}_{20} \mathrm{O}$ & Decanal \\
\hline
\end{tabular}

Table 4: Chemical composition of Nostoc sp. N27P72 (Cu(II)) extracts as revealed by gas chromatography mass spectrophotometry (GC-MS). 


\begin{tabular}{|c|c|c|c|c|c|}
\hline $\begin{array}{l}\text { Area } \\
\%\end{array}$ & RT & $\begin{array}{l}\text { Nature of the } \\
\text { compound }\end{array}$ & $\begin{array}{l}\text { Molecular } \\
\text { weight }\end{array}$ & $\begin{array}{l}\text { Molecular } \\
\text { Formula }\end{array}$ & Name of Compound \\
\hline $78 \%$ & 11.63 & $\begin{array}{l}\text { Heterocyclic } \\
\text { compound }\end{array}$ & 138.3 & $\mathrm{H}_{6} \mathrm{O}_{3} \mathrm{Si}_{3}$ & Cyclotrisiloxane \\
\hline $78 \%$ & 11.71 & $\begin{array}{l}\text { Heterocyclic } \\
\text { compound }\end{array}$ & 138.3 & $\mathrm{H}_{6} \mathrm{O}_{3} \mathrm{Si}_{3}$ & Cyclotrisiloxane \\
\hline $90 \%$ & 15.89 & $\begin{array}{l}\text { Heterocyclic } \\
\text { compound }\end{array}$ & 138.3 & $\mathrm{H}_{6} \mathrm{O}_{3} \mathrm{Si}_{3}$ & Cyclotrisiloxane \\
\hline $7 \%$ & 16.31 & methyl ketones & 84.12 & $\mathrm{C}_{5} \mathrm{H}_{8} \mathrm{O}$ & 4-penten-2-one \\
\hline $90 \%$ & 19.61 & $\begin{array}{l}\text { Heterocyclic } \\
\text { compound }\end{array}$ & 138.3 & $\mathrm{H}_{6} \mathrm{O}_{3} \mathrm{Si}_{3}$ & Cyclotrisiloxane \\
\hline $43 \%$ & 23.26 & mono ester & 166.1308 & $\mathrm{C} 8 \mathrm{H} 6 \mathrm{O} 4$ & $\begin{array}{l}\text { 1,2-Benzenedicarboxylic } \\
\text { acid }\end{array}$ \\
\hline $91 \%$ & 23.42 & mono ester & 166.1308 & $\mathrm{C} 8 \mathrm{H} 6 \mathrm{O} 4$ & $\begin{array}{l}\text { 1,2-Benzenedicarboxylic } \\
\text { acid }\end{array}$ \\
\hline $80 \%$ & 23.54 & $\begin{array}{l}\text { diester of phthalic } \\
\text { acid }\end{array}$ & 390.6 & $\mathrm{C}_{24} \mathrm{H}_{38} \mathrm{O}_{4}$ & $\begin{array}{l}\text { Bis(2-ethylhexyl) } \\
\text { phthalate }\end{array}$ \\
\hline $91 \%$ & 23.81 & mono ester & 166.1308 & $\mathrm{C} 8 \mathrm{H} 604$ & $\begin{array}{l}\text { 1,2-Benzenedicarboxylic } \\
\text { acid }\end{array}$ \\
\hline $91 \%$ & 24.03 & mono ester & 166.1308 & $\mathrm{C} 8 \mathrm{H} 6 \mathrm{O} 4$ & $\begin{array}{l}\text { 1,2-Benzenedicarboxylic } \\
\text { acid }\end{array}$ \\
\hline $91 \%$ & 24.15 & mono ester & 166.1308 & $\mathrm{C} 8 \mathrm{H} 6 \mathrm{O} 4$ & $\begin{array}{l}\text { 1,2-Benzenedicarboxylic } \\
\text { acid }\end{array}$ \\
\hline $91 \%$ & 24.57 & mono ester & 166.1308 & $\mathrm{C} 8 \mathrm{H} 6 \mathrm{O} 4$ & $\begin{array}{l}\text { 1,2-Benzenedicarboxylic } \\
\text { acid }\end{array}$ \\
\hline $91 \%$ & 25.05 & mono ester & 166.1308 & $\mathrm{C} 8 \mathrm{H} 6 \mathrm{O} 4$ & $\begin{array}{l}\text { 1,2-Benzenedicarboxylic } \\
\text { acid }\end{array}$ \\
\hline $91 \%$ & 25.54 & mono ester & 166.1308 & $\mathrm{C} 8 \mathrm{H} 6 \mathrm{O} 4$ & $\begin{array}{l}\text { 1,2-Benzenedicarboxylic } \\
\text { acid }\end{array}$ \\
\hline
\end{tabular}

\section{Figures}



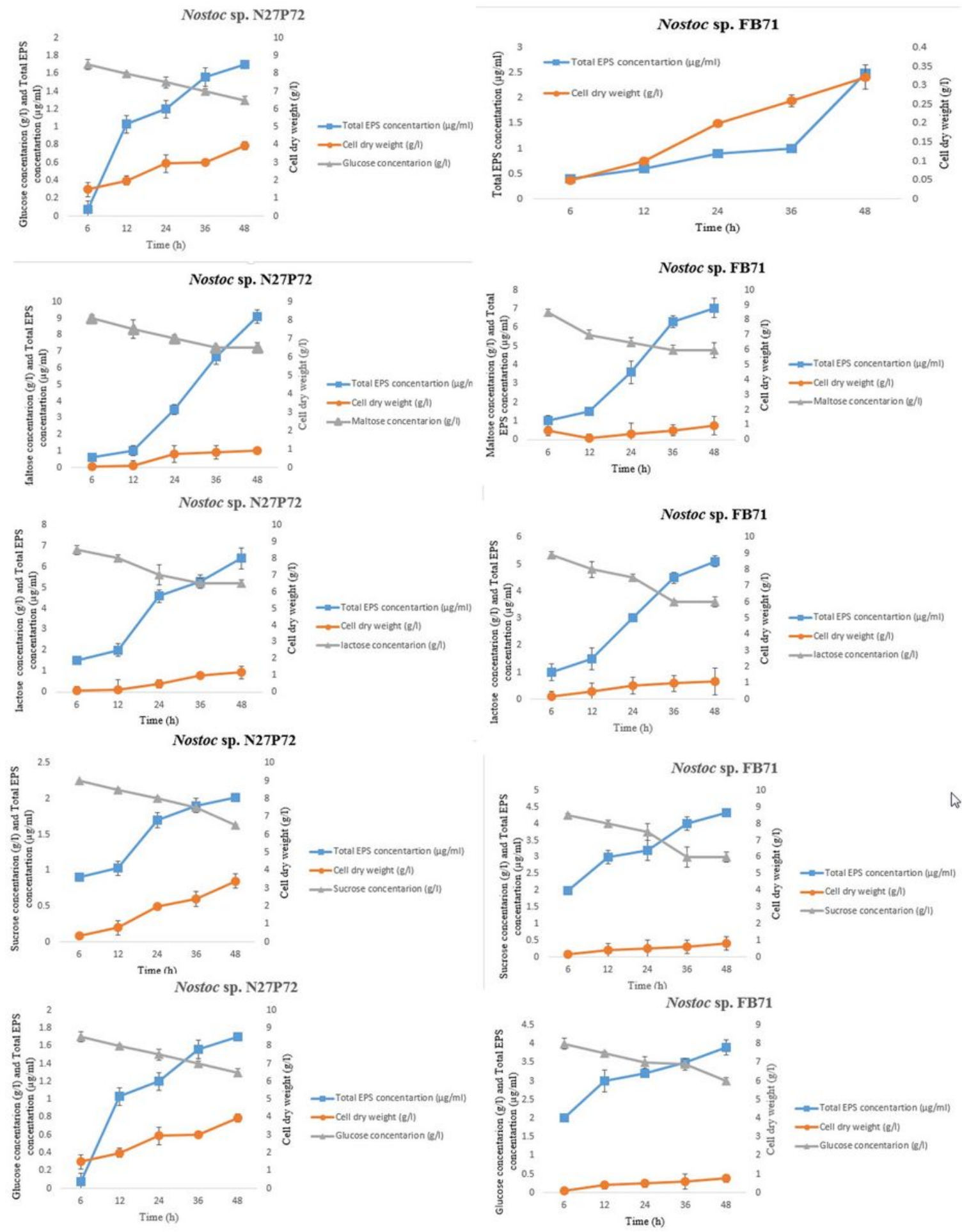

\section{Figure 1}

Growth profile and EPS production of Nostoc sp. N27P72 and Nostoc sp. FB71 cultivated in media culture containing $(10 \mathrm{~g} / \mathrm{l})$ glucose, sucrose, lactose and maltose, separately and media culture without additional sugars as a control. Symbols indicate ( $(\bullet)$ for cell dry weight, $(\square)$ for total EPS concentration, and $(\Delta)$ for sugar concentration in the media. Results are the mean of duplicate measurement. 
Nostoc sp. N27P72

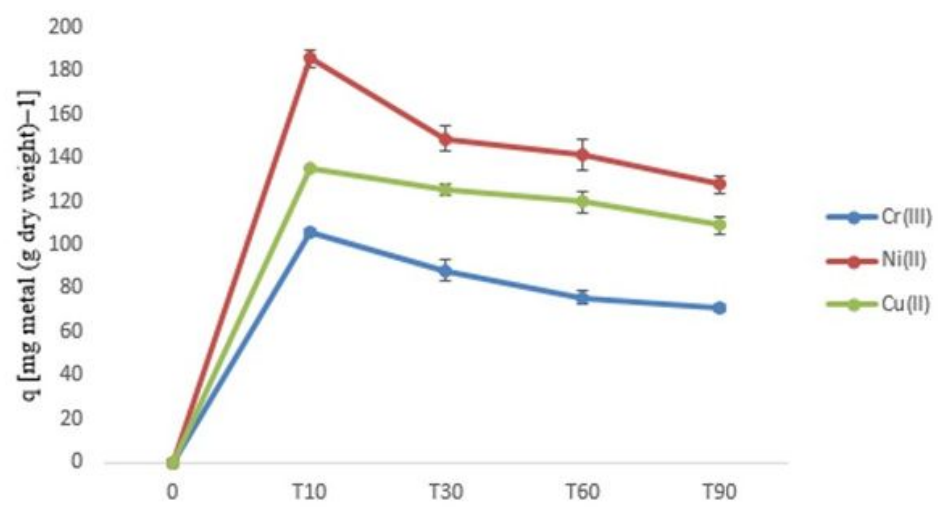

Nostoc sp. FB71

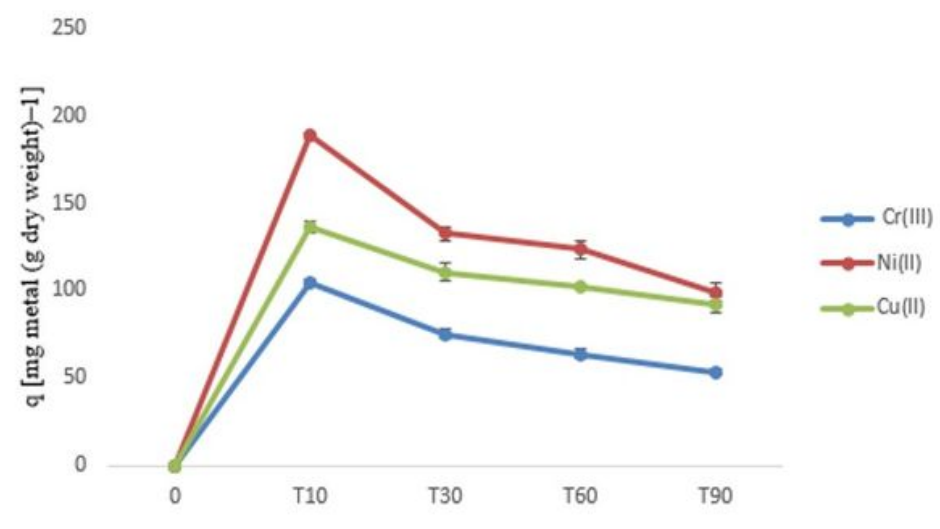

\section{Figure 2}

Time course of specific metal removal (q), expressed as mg of metal removed per $\mathrm{g}$ of biomass dry weight, by Nostoc sp. N27P72 and Nostoc sp. FB71 cultivated in media culture containing (10 g/l) maltose, with copper, chromium and nickel in single-metal solutions. Symbols represent the mean of at least three replicates and bars represent the standard deviation, if larger than the dimensions of the symbols.
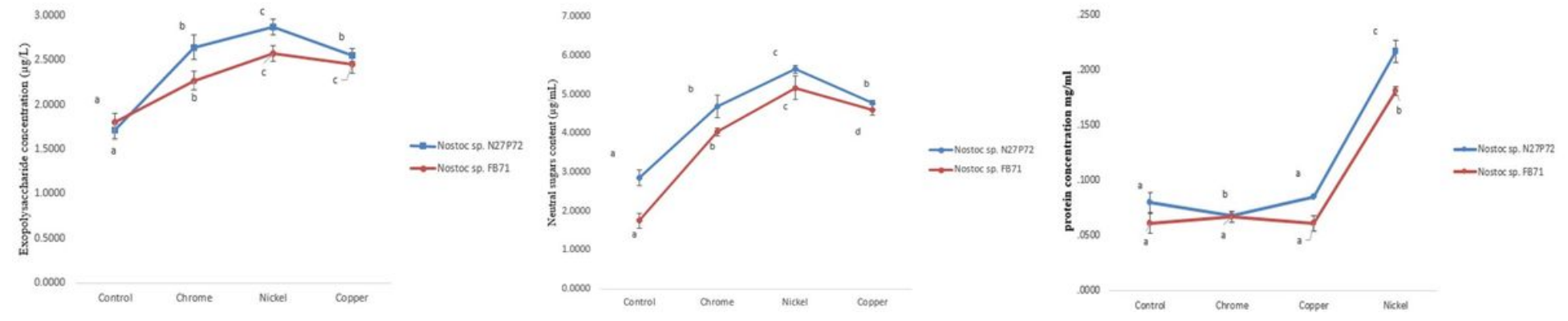

Figure 3

Comparison of total produced EPSs (a), Neutral sugar content (b) and total soluble proteins (c) of Nostoc sp. N27P72 and Nostoc sp. FB71 in lyophilized EPS containing maltose and metal solution of $\mathrm{Cu}(\mathrm{II}), \mathrm{Cr}(\mathrm{III})$ and $\mathrm{Ni}(I I))$. All the values are mean of at least three replicates \pm standard deviation. 


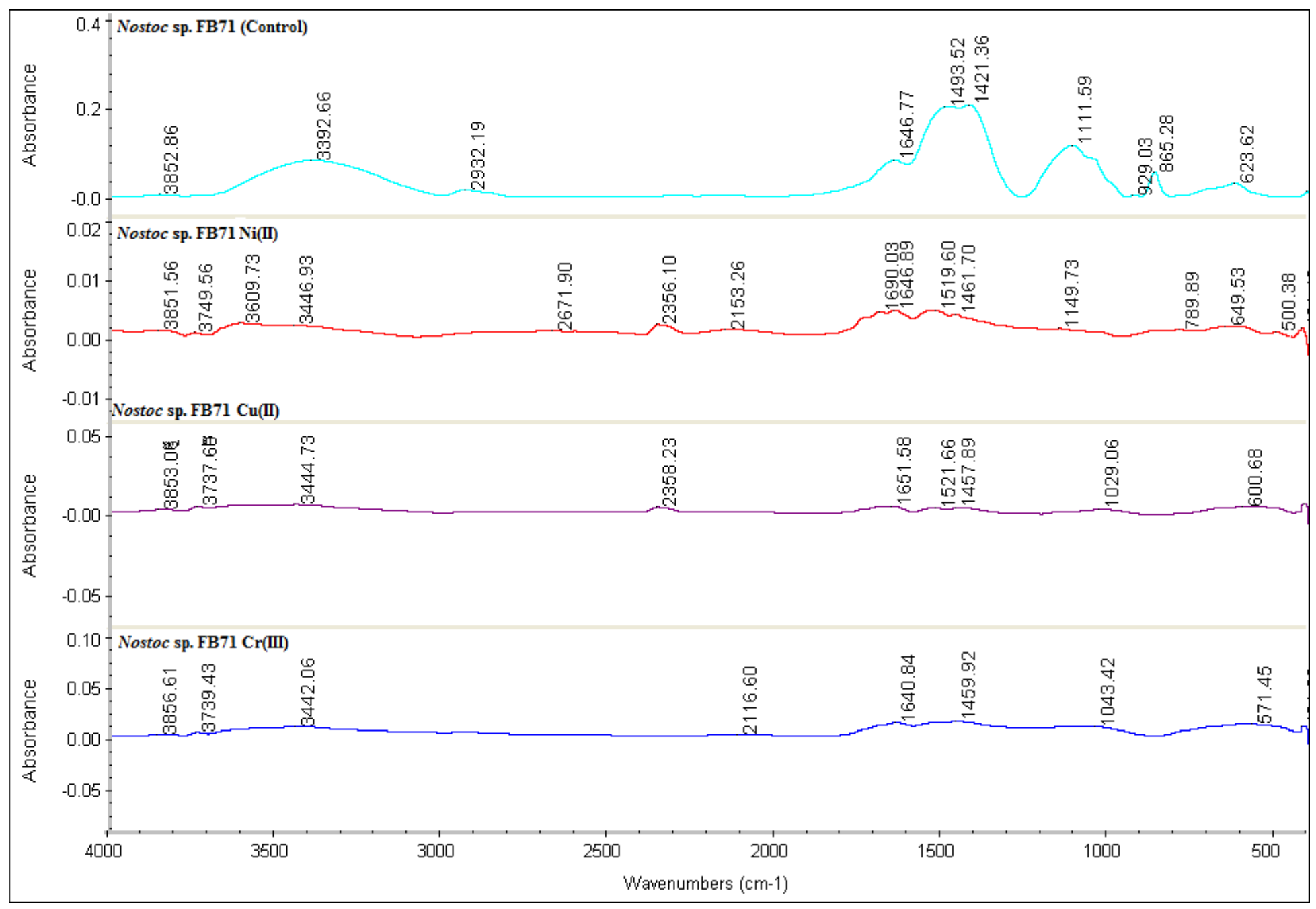

Figure 4

Fourier transform infrared (FTIR) spectra of EPS from Nostoc sp. FB71 against control or exposure to a solution containing $400 \mathrm{ml}$ of cell suspensions in $1000 \mathrm{ml}$ Erlenmeyer flasks of $\mathrm{Cu}(\mathrm{II}), \mathrm{Cr}(\mathrm{III})$ and $\mathrm{Ni}(\mathrm{II})$. 


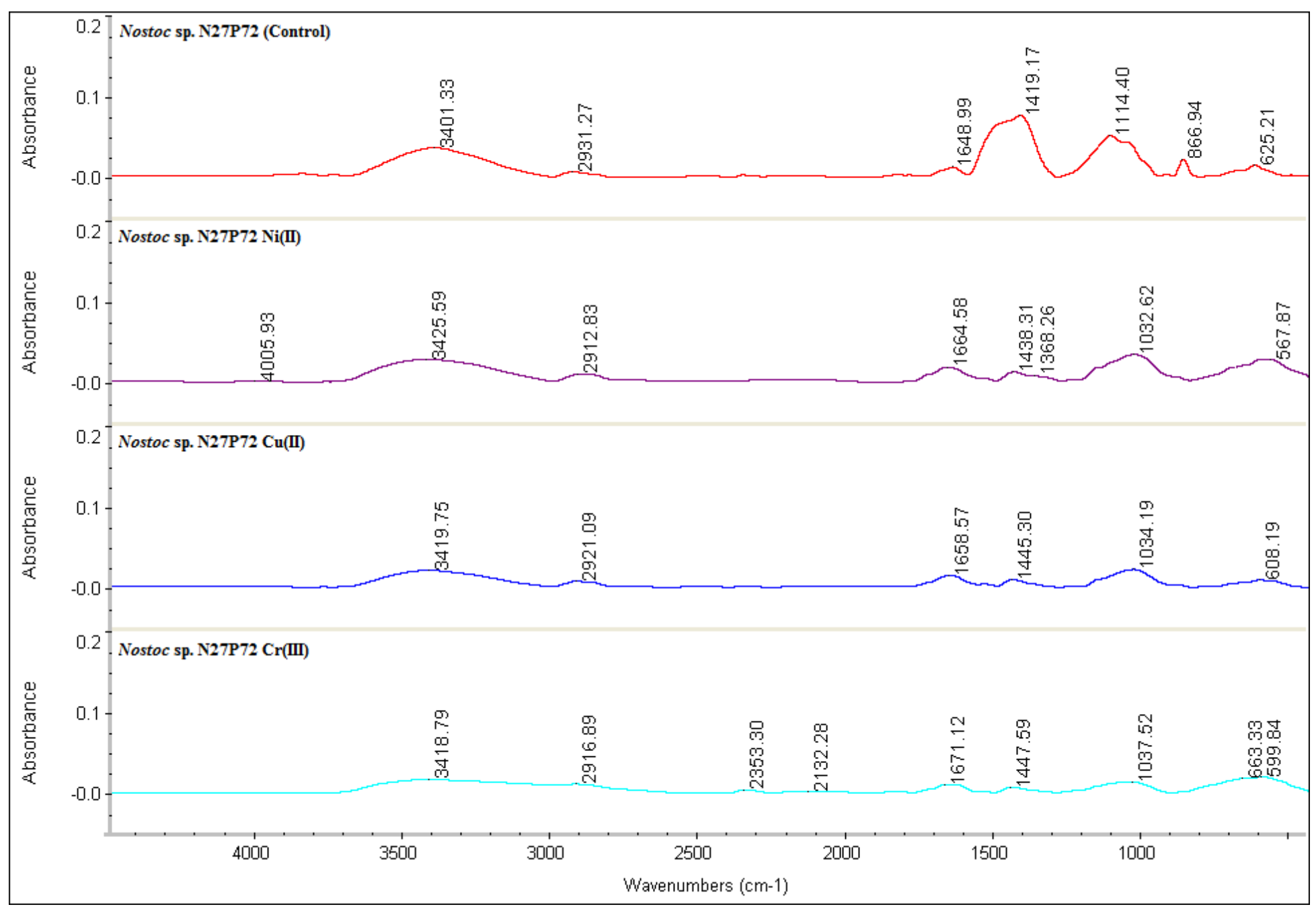

Figure 5

Fourier transform infrared (FTIR) spectra of EPS from Nostoc sp. N27P72 against control or exposure to a solution containing $400 \mathrm{ml}$ of cell suspensions in $1000 \mathrm{ml}$ Erlenmeyer flasks of $\mathrm{Cu}(\mathrm{II}), \mathrm{Cr}(\mathrm{III})$ and $\mathrm{Ni}$ (II).

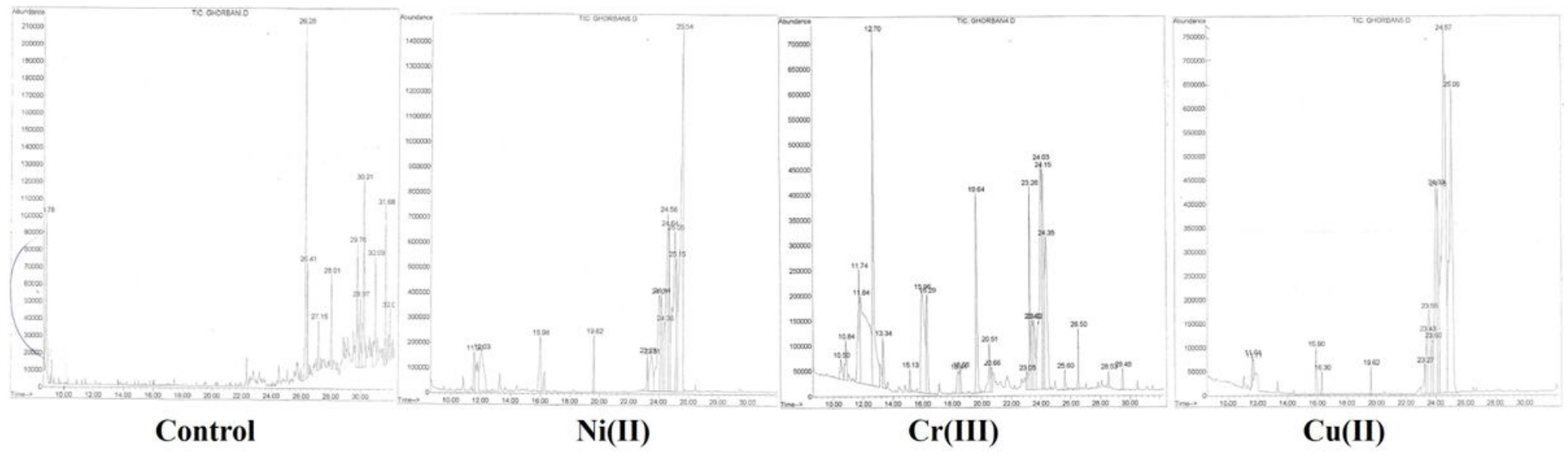

Figure 6

GC-MS chromatogram of the extract of Nostoc sp. N27P72, in media culture containing the maltose and without maltose as control culture, were tested for their ability to remove $\mathrm{Cu}(\mathrm{II}), \mathrm{Cr}(\mathrm{III})$ and $\mathrm{Ni}(\mathrm{II})$. 